\title{
NOTES ON A PRIVATE LIBRARY IN FOURTH/TENTH-CENTURY BAGHDAD
}

\author{
Letizia Osti \\ UNIVERSITÀ DEGLI STUDI DI MILANO
}

\begin{abstract}
Studies on medieval Arabic bibliophilia have mainly focussed on public and semi-public institutions, for some of which we have detailed information. Less is known about private libraries and their physical arrangement. This paper looks at the library of Abū Bakr al-Șūlī (d. 335/947), which is described by the sources in unique terms, contextualising it with al-Ṣūlī's own words on collecting and organizing books.
\end{abstract}

The importance of bibliophilia and its by-product - the library-for medieval Arabic culture is well documented in the sources and has been studied by scholars since the 1800 s. $^{1}$ Information has come down to us not only on public and semi-public libraries such al-Ma ${ }^{3}$ mūn's hizānat al-hikma and institutions connected to madrasas, but also on collections held by private individuals. However, while for the former we do have information on the physical spaces containing the books and on their arrangement, descriptions of early private libraries mainly restrict themselves to the amount of books they contained, their value, and the subjects they covered. The fourth/tenth-century bookseller and bibliophile Ibn al-Nadīm, for instance, mentions that the historian alWāqidī (d. 207/823) had left at his death six hundred cases full of books, each of which could only be carried by two men. ${ }^{2}$ Accounts such as this are frequent, and modern scholars have been able to collect detailed information on the libraries of specific individuals who lived in late and post- ${ }^{\mathrm{C}} \mathrm{Abba} s i d$ times. ${ }^{3}$ However, the library as a physical space, and the organization and arrangement of books within it are rarely mentioned.

Ibn al-Nadīm cites eleven individuals as book-collectors ( $\check{\text { gamm }} \bar{a}^{c} a l i$ l-kutub). ${ }^{4} \mathrm{He}$ also mentions actual libraries (hizāna), two of which belonged to caliphs, saying of one private library, which he had

\footnotetext{
1 An early example is É. Quatremère, Mémoire. More recent studies are cited below.

2 Ibn al-Nadīm (d. 380/990), Fihrist, 1, part 2: 308.

3 For instance, U. Haarmann, 'Library'; and E. Kohlberg, A Medieval Muslim Scholar. For a sociological profile of the book-collector across centuries and cultures, see H. Touati, Armoire, 30-9.

4 Fihrist, indexes, 2, part 2: 932 and 933 respectively.
} 
personally visited, that it was the largest he had ever seen. ${ }^{5}$ Its owner, Muhammad b. al-Husayn b. Abī $\mathrm{Ba}^{\mathrm{c}}$ rah, kept antique and precious books in a case there, which he took out to show to Ibn al-Nadīm. The case (qimatr) weighed 300 raț and contained writings on different materials, heavily annotated by successive owners. Unfortunately, after the owner's death, Ibn al-Nadim lost track of the case and its contents. ${ }^{6}$

Ibn al-Nadīm does not give any physical details for the other libraries he mentions in the Fihrist. However, he says that he had seen a notebook (daftar) coming from the library of another individual whom he identifies as a collector: the courtier, litterateur and chess-player Abū Bakr al-Șūlī (d. 335/947). This notebook is the proof that al-Șūlì was a plagiarist:

[...] A Biography and Selected Poetry of Sudayf [d. 147/764]. For the composition of this book he relied on the book of al-Martadī [d. 286/899], Poetry and Poets, or rather he copied it word by word and plagiarized it. I have seen the notebook in the handwriting of the man himself; it came from the library of al-Ṣūlī, so it all became clear. ${ }^{7}$

A more unusual description of the library of al-Șūlī is recorded by alHațīb al-Bag̉dādī:

[...] I saw that al-Ṣūlī had an enormous apartment full of books which were arranged into rows. Their bindings were of different colours, each row of books in a colour: one row was red, another green, another yellow, etc. [... al-Sūlī] would say: 'All these books are notes from lectures I have attended'. 8

Al-Șūlī's claim in the last sentence deserves investigation. He says 'hadihi l-kutub kulluhā sama $\bar{a}^{c} \bar{l}$.' Sellheim ties $\operatorname{sam} \bar{a}^{c}$ to the establishment of madrasas in the late fifth/eleventh century. In that context, it indicates a written attestation that an individual has attended lectures on a certain book. ${ }^{9}$ That the term is used in reference to al-Șūlì may indicate that a similar procedure was in practice earlier than the period proposed by Sellheim; this is in fact what Toorawa's translation of this passage

5 Al-Mu' ${ }^{\mathrm{c}}$ tadid (Fihrist, 1, part 1: 177) and al- Ma ${ }^{\circ}$ mūn (1, part 1: 13 and 15); see footnote 2 on p. 13 for this library and al-Macmūn's bayt al-hikma).

6 Fihrist, 1, part 1: 106-8.

7 Fihrist, 1, part 1: 465. For a physical description of a daftar see J. M. Bloom, Paper before Print, 140-1.

8 Al-Hatị̄b al-Baġdādī (d. 463/1071), Ta rīh Bağdād, 5: 202.

9 R. Sellheim, 'samā'c'. 
implies. ${ }^{10}$ However, al-Șūlī may intend with $\operatorname{sam}^{c}$ not a written document but simply the act of auditing the lectures and taking notes. Therefore, it is possible to interpret the statement as saying not that his books are his lectures, but that he has attended lectures on the contents of all of them. Many of al-Șūlī's books would indeed have been dafātir, notebooks from lectures which he then might use to compose his own works. ${ }^{11}$ However, if Ibn al-Nadīm's testimony above is to be believed, not all of these were his own work.

Al-Sūlin's claim is important because it introduces the next two accounts in his biography: when asked a scholarly question, we are told, al-Șūlī would not answer immediately from his memory, but would call a servant and have a book brought to him. 'Al-Șūlī is indeed a scholar', says a short satire, 'but only to the extent that he can look things up in a book'. ${ }^{12}$ Once again, as in the Fihrist, the implications of being a book collector are not wholly positive.

Let us return to the material details: al-Ṣūlī's books were not, or not all, stored in a qimatr, a case made of woven reeds, but filled a large apartment (bayt), where they were arranged in rows (mașfüfa), each of which had leather bindings ( $\check{g} u l \bar{u} d)$ of a different colour. The first part of the statement appears to be illustrated precisely by a miniature on a Baghdadi manuscript copied in 634/1237: books would be stacked in little piles on shelves divided into sections. ${ }^{13}$ On the other hand, the

10 S.M. Toorawa, Ibn Abī Țāhir Tayfūr, 23: 'all these books are my certificates of audition.'

11 See also the first two chapters of G. Schoeler, The Oral and the Written, 28-86; idem and S. M. Toorawa, The Genesis of Literature, 128. According to Schoeler's definition, these would be hypomnema. More information and further bibliography on this topic can be found in Konrad Hirschler's contribution to this volume.

12 Ibid. Later sources merge these three successive accounts. However, in alHațib's biography, which is the earliest, these are juxtaposed but distinct. The question is discussed in more detailed in my 'Tailors of Stories'.

$13 \mathrm{BnF}$ Arabe 5847, 5v. The entire manuscript is available for download from the website of the Bibliothèque nationale de France http://gallica.bnf.fr/. The miniature is described by Pinto, 'The Libraries of the Arabs', 229. A black and white image of it was first published by E. Blochet, Les Enluminures des manuscrits orientaux, table X. Versions in colour can be found in J. Bloom, Paper before Print, 119; and in H. Touati, Armoire, fig. 23b. Although the miniature was painted much later than al-Șūlì's lifetime, it seems to be the earliest extant representation of a library. See also Quatremère, Mémoire, especially 27-30, where the sale of a Fâtimid library is described: in order to disguise the price of the books and being able to buy them for a very low price, 
arrangement in different colours is, as far as I could ascertain, unique. While the description does not necessarily imply that the books were colour-coded, it does suggest that their arrangement followed a precise criterion. If the books were already bound when al-Ṣūli acquired them, this criterion might have been exclusively aesthetic. If, however, he had them bound himself - and this must have been the case at least for his own notebooks - a different rationale may be considered. ${ }^{14}$ Another biographer, Yāqūt (d. 626/1229), comments on the arrangement of alȘūlī's books:

Abū Bakr al-Ṣulī had a library which he had devoted to the different books he had collected. He had arranged them in it in the best of orders. ${ }^{15}$

Yāqūt does not specify which order might be the best. It seems wellestablished that in public libraries books were placed on shelves in the same order in which they appeared in the catalogue, which in turn was arranged by subject. ${ }^{16}$ However, within this broad principle there is still much room for manoeuvre and for doubt. For instance: how to organise single books within the same subjects? Should lecture notes be separate from copied manuscripts? In the Fihrist Ibn al-Nadìm employs different criteria (alphabetical, chronological, etc.), not always explicitly, within each of the ten subjects in which he organises his catalogue. ${ }^{17}$ In his

the courtiers in charge of the sale took them out of their cases and mixed up their arrangement by subject (this story is retold by Touati, Armoire, 294). A brief overview is also found in W. Heffening [J.D. Pearson]), 'Maktaba.' All these studies deal mainly with public or semi-public libraries.

$14 \mathrm{Ibn}$ al-Nadīm lists the names of nine famous book binders (muğallid), the first of whom worked for al-Ma ${ }^{\circ}$ mūn's bayt al-hikma; he also briefly discusses the quality of leather used for bindings (Fihrist, 1, part 1: 24 and 48-9 respectively). Different binding techniques are illustrated by R. Selleim, 'Kitāb.' J. Bloom, Paper before Print, 111-13 provides a drawing detailing different part elements of the book. Pedersen, The Arabic Book, 101-12, devotes a chapter to bookbinding.

${ }^{15}$ Yāqūt b. ${ }^{c} \mathrm{Abd}$ Allāh al-Ḥamawī, Mu' ğam al-udabāa, 2677 (biography no. 1134).

16 Y. Eche, Bibliothèques, 338. Eche does not mention differences in colour and indeed mentions bindings only tangentially. See also H. Touati, Armoire, 291-317 and note 13 above on the Fātimid library. These studies also discuss the subjects making up library collections.

17 The most thorough investigation of this topic, referring also to earlier studies, is S.M. Toorawa, 'Proximity'. A late sample of the practical problems faced by a cataloguer is illustrated in Konrad Hirschler's contribution to this volume. 
$M u^{c}$ jam al-udaba $\bar{a}^{\supset}$, where al-Ṣūlì’s biography is found, Yāqūt arranges his entries in strict alphabetical order, one of the earliest compilers to do so consistently. Whether this is 'the best of orders' to which he refers, it is impossible to know.

In fact, this attention to the physical arrangement of books mirrors a skill displayed by al-Șūlī in his own writings: according to his student alMarzubānī (d. 384/994), he had 'ability in composing books and collocating their elements in the proper place'. ${ }^{18}$ This is a skill al-Șūli has in common with an earlier and more famous fellow-book collector, al-Ğạhiz (d. 255/868-9); it is the skill of the author who writes for a readership. ${ }^{19}$

Al-Șulî̀'s love for books transpires in his own work, and especially in his chronicles of the caliphate, where he often gives information about himself, such as the Ahbār al-Muqtadir and Ahbār al-Rāḍ̄ bi-llāh wa-lMuttaqi li-llāh. For instance, he is proud to have transmitted his passion to younger generations. In 312/924-925 he relates that he was appointed tutor of the princes Abū 1- ${ }^{\mathrm{c}} \mathrm{Abbās}$ and $\mathrm{Abu \overline { }}{ }^{\mathrm{c}} \mathrm{Abd}$ Allāh, sons of the caliph al-Muqtadir (r. 295/908-320/932). Al-Ṣūī taught them to use notebooks and had them learn traditions. The two boys were so enthusiastic that 'the price of notebooks went as high as it had ever been in a long time,' and 'paper and book merchants [warrāqin] became rich' ${ }^{20}$ In addition, the princes also became collectors: ${ }^{21}$

I instilled in them the love of knowledge and bought them a good deal of books on jurisprudence, poetry, lexicography and chronicles. They competed, each putting together his own library.

What is interesting in this passage is that the boys take acquisitions in their own hands at such a young age. This can be compared with the education of their father, the caliph al-Muqtadir, for whom dafätir and other educational tools were selected by his father al-Muctadid (r. 279/892-289/902) with the help of Sinān b. Tābit (d. 331/943), the court

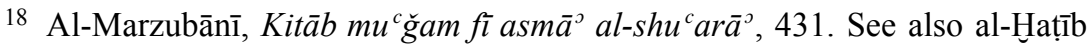

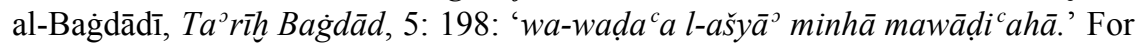
an evaluation of al-Ṣūlī as an historian see also Abū l-Hasan ${ }^{c}$ Alī b. al-Husayn alMas $^{\mathrm{c} u ̄ d} \overline{1}$ (d. 345/956), Les Prairies d'or - Murūğ al-dahab, 1: 15 (§11).

19 Ibid., 5: 104 (§ 3146): '[...] nazzamahā ahsan naẓm wa-rașafahā ahsan rasff.' See Schoeler and Toorawa, The Genesis of Literature, 59, 68-84, 111-21.

20 Al-Ṣūlī, Mā lam yunšar min awrāq al-Ṣūlī, 144.

21 Al-Șūīi, Ahbā̄r al-Rā ḍ̄ bi-llāh, 25. 
physician. This material came from 'the old caliphal repositories' (alhazāं in al-qadīma li-l-sultān).22

Later, after Abū 1- ${ }^{\mathrm{c}}$ Abbās has become the caliph al-Rāḍī, al-Ṣūī discusses with his former pupil the contents of the library which he had 'put together like the previous caliphs.' Al-Ṣūlī is surprised that it should not contain the dīwān of a certain poet and advises the caliph as follows:

Begin by arranging the works of poetry ( ${ }^{c} a m a l$ al-a $\check{s}^{c} \bar{a} r$ ), starting with the Mudar tribe, than $\operatorname{Rabi}^{c}$ a, then Yaman. What is not there, your servants will bring to you from their own stock. Whatever they only have as lecture notes ( $m \bar{a}$ kāna sam $\bar{a}^{c} a n{ }^{2}{ }^{c}{ }^{c} a b i \bar{d} i k a$ ), and whatever they cannot replace, the copyists you appoint will copy it and the binders of the library will bind it. ${ }^{23}$

Al-Șùlī continues to say that, although his own library may be diminished by this, he cannot stand for the caliph to have something that is not perfect. After this discussion, al-Rāḍi decides to donate his library to his sons: day after day, he has books brought to him and proceeds, with the help of his courtiers, to divide them up between the two princes, keeping some for himself and leaving the least valuable to the courtiers, who sell them by weight.

This episode corroborates two hypotheses advanced above: first, alȘūli advises the caliph to arrange his books by subject, and within the subject he suggests a subordinate criterion - for classical poetry it is an arrangement by tribe, but one may imagine different rationales for other subjects. Second, the caliph will have his copyists reproduce those works which the courtiers only have as $\operatorname{sam} \bar{a}^{c}$, which here it seems uncontroversial to understand as lecture notes.

We hear again, tangentially, of al-Șūlî’s library in 329/941, when alȘūlī's home is ransacked. Amongst other precious objects, 'they found a portion of my notebooks, which they pillaged'. ${ }^{24} \mathrm{He}$ is now poor, he says, and survives on the revenue of a garden he owns and on his notebooks. ${ }^{25}$ While the expression 'the price of my notebooks' (atmān dafātirì) may imply an actual sale, it seems unlikely that he would sell the tools necessary for obtaining an income: the expression might also

22 F. Rosenthal, Muslim Historiography, 48, quoting Ibn al- ${ }^{\mathrm{c}}$ Adīm's Buġya; the Arabic text is on pages 541-2. See also A.S. Tritton, Materials, 168.

23 Al-Șūīi, Ahbār al-Rāộ̀ bi-llāh, 39-40.

24 Ibid., 210.

25 Ibid., 211. 
mean that al-Ṣūlī used these notebooks for teaching, or that he rented them out to other scholars. ${ }^{26}$

In fact, at this time al-Ṣūli is in Bașra, and one of his student is a young al-Tanūhī (d. 384/994), who will go on to become a judge and $a d a b$ author. In al-Farağ $b a^{c} d a l$ l-šidda al-Tanūkhī recalls that when he was a boy his father had been appointed testator for al-Ṣūlī, who had not named any heirs in his testament. However, when the scholar died in Bașra in 335/947, three poor brothers went to al-Tanūhī's father, claiming that their mother had been related to al-Șūlì. At length, they produced the necessary testimony and were awarded a portion of the inheritance, which the judge had converted into money in the meantime. Unfortunately, al-Tanūhī does not specify the amounts of money involved, nor does he say whether the possessions left by al-Șūi included books. ${ }^{27}$ As mentioned above, at least one daftar survived into the late fourth/tenth century and was seen by Ibn al-Nadīm.

Information on al-Ṣūlì's library is too scarce to allow a precise picture to emerge, and leaves us with more questions than answers, beginning with the obvious ones: which titles did it contain? Were these all lecture notes, as the scholar claimed? How many of these were personal, and how many had been acquired? How much did he spend to keep expanding the collection? How were the books organised exactly? Were they only for his personal use? Despite this uncertainty, what seems to be implicit in all the snippets of description found in the sources and discussed above is that al-Șūlî's library was remarkable, and not only in the eyes of its owner, for its physical appearance as well as for its contents.

Reflecting on this material has also highlighted practical differences between a public library and a private one: for instance, al-Ṣūlì's servants must have been conversant with the arrangement of the library if they were able to find a book when ordered to do so. However, it is not clear whether any of these servants were employed exclusively to look after them as librarian, cataloguer, copyist or binder. Moreover,

26 Pedersen, Arabic Book, 34, mentions cases where scholars borrowed books from senior colleagues for copying (quoting Yāqūt, $M u^{c}$ ğam, 2722), although it is not clear whether this implied a money transaction. I am grateful to Antonella Ghersetti for this reference as well as for many helpful comments and suggestions on the first draft of this paper. I should also like to thank the anonymous reviewers.

27 Al-Tanūh̄ī, al-Farağ bacd al-šidda, 3: 262-7 (story no. 328). The eldest brother, Abū ${ }^{\mathrm{c}}$ Alī Aḥmad b. Muhammad b. Ğa ${ }^{c}$ far, later adopted al-Ṣulī as his šuhra. He has a short entry in al-Hatịib's Ta rīh Bağdād, 4: 407. 
maintaining a library was an investment: it could contribute to its owner's income, help him get into the good graces of a patron, or be part of his inheritance. Finally, al-Șūlì's ambiguous reputation as a scholar knowledgeable, but only in writing; a good poetry editor, but a plagiarist - reflects a well-known conflictual relationship between the oral and the written in medieval Arabic culture.

\section{BIBLIOGRAPHY}

Primary sources

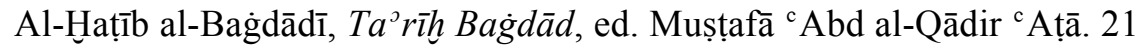
vols, Beirut: Dār al-kutub al-cilmiyya, 1997.

Ibn al-Nadīm, Muḥammad b. Isḥāq, Kitāb al-Fihrist, ed. A.F. Sayyid. London: al-Furqan Islamic Heritage Foundation, 2009.

Al-Marzubānī, Abū ${ }^{\mathrm{c}}$ Ubayd Allāh Muhammad b. ${ }^{\mathrm{c}}$ Imrān b. Mūsā, Kitāb

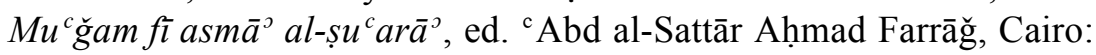
Dār ihyāa al-kutub al-carabiyya/Mușțafā al-Bābī al-Ḥalabī waawlāduhu, 1960.

Al-Mas ${ }^{\mathrm{c}} \overline{\mathrm{d}} \mathrm{i}, \mathrm{Abu}$ l-Ḥasan ${ }^{\mathrm{c}}$ Alī b. al-Ḥusayn, Les Prairies d'or - Murūğ $a l-\underline{d} a h a b w a-m a^{c} \bar{a} \underline{d}$ in al-ğawhar, ed. Barbier de Meynard et Pavet de Courteille; revue et corrigée par Charles Pellat, 7 vols, Beirut: Publications de l'Université Libanaise, 1965-79.

Al-Ṣūlī, Abū Bakr, Ahbār al-Rāẹ̄ bi-llāh wa-l-Muttaqī li-llāh, aw, Ta rīhh al-dawla al- ${ }^{c}$ abbāsiyya min sanat 322 ilā sanat 333 hiğriyya min Kitāb al-awrāq, ed. J. Heyworth Dunne, Beirut: Dār al-masīra, 1934-6.

—-, Mā lam yunšar min awrāq al-Șūlū: ahbār al-sanawāt 295-315, ed. Hilāl Nāğī, Beirut: ' ${ }^{\circ} \bar{A} l a m$ al-kutub, 2000.

Al-Tanūhīi, Abū ${ }^{c}$ Alī al-Muhassin, al-Farağ $b a^{c} d a$ l-šidda, ed. ${ }^{c} A b b u ̄ d$ al-Šāliğī, 5 vols, Beirut: Dār șādir, 1978.

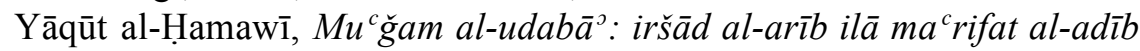

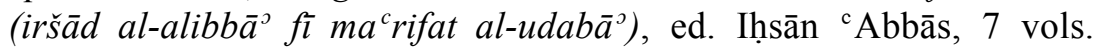
Beirut: Dār al-gaarb al-islāmī, 1993.

\section{Secondary studies}

Bearman, P., et al., (eds.) Encyclopaedia of Islam, 2nd ed., 12 vols, Leiden and Paris: Brill-Maisonneuve, 1960-2009.

Blochet, Edgar, Les Enluminures des manuscrits orientaux - turcs, arabes, persans - de la Bibliothèque nationale, Paris: Gazette des Beaux-Arts, 1926. 
Bloom, Jonathan M, Paper before print: the history and impact of paper in the Islamic world, New Haven: Yale University Press, 2001.

Eche, Youssef, Les Bibliothèques arabes publiques et semi-publiques en Mésopotamie, en Syrie et en Égypte au Moyen Age, Damascus: Institut Français de Damas, 1967.

Haarmann, Ulrich, 'The Library of a Fourteenth-Century Jerusalem Scholar', Der Islam 61 (1984), 327-33.

Heffening W., [J.D. Pearson]), 'Maktaba'. $E I^{2}$, vi, 197-200.

Kohlberg, Etan, A Medieval Muslim Scholar at Work: Ibn Țāwūs and his Library, Leiden: Brill, 1992.

Osti, Letizia. 'Tailors of Stories: Biographers and the Lives of the khabar', Synergies Monde Arabe 6 (2009), 283-91.

Pedersen, Johannes. The Arabic Book. Translated by Robert Hillenbrand. Princeton: Princeton University Press, 1984.

Pinto, Olga, 'The Libraries of the Arabs during the Times of the Abbasids', transl. F. Krenkow, Islamic Culture 3 (1929), 210-43.

Quatremère, Étienne, Mémoire sur le goût des livres chez les orientaux: extrait du Journal Asiatique (III série). [Paris]: Imprimerie Royale, 1838.

Rosenthal, Franz, A History of Muslim Historiography, 2nd ed. Leiden: Brill, 1968.

Schoeler, Gregor, The Oral and the Written in Early Islam,transl. Uwe Vagelpohl; ed. James E. Montgomery, London: Routledge, 2006.

- (in collaboration with Shawkat M. Toorawa). The Genesis of Literature in Islam: From the Aural to the Read, Edinburgh: Edinburgh University Press, 2009.

Sellheim, R., 'Kitāb', $E I^{2}$, v, 207-8.

—, 'Samā' ', $E I^{2}$, viii, 1019-20.

Toorawa, Shawkat M., Ibn Abī Tāhir Tayfür and Arabic Writerly Culture: a Ninth Century Bookman in Baghdad, London and New York: RoutledgeCurzon, 2005.

Toorawa, Shawkat M., 'Proximity, Resemblance, Sidebars and Clusters: Ibn al-Nadīm's Organizational Principles in Fihrist 3.3.' Oriens 38 (2010), 217-47.

Touati, Houari, L'Armoire à sagesse: bibliothèques et collections en Islam, Paris: Aubier, 2003.

Tritton, Arthur Stanley, Materials on Muslim Education in the Middle Ages, London: Luzac, 1957. 